\title{
I11インボリュート曲線の最適円弧補間の簡易方法
}

\section{A Simplified Method of Optimal Circular Arc Interpolation for Involute Curves}

\author{
正 丘 華 (九産大)， ○学 西島 祐次郎（九産大院）
}

Hua QIU and Yujiro NISHIJIMA, Kyushu Sangyo University, 2-3-1 Matsukadai, Higashi-ku, Fukuoka-city

Key Words: Involute Curve, Optimal Circular Arc Interpolation, Calculation Algorithm

\section{1. 緒言}

曲線輪郭の設計・加工・計測を簡便に行うために，従来 インボリュート曲線を円弧で近似または補間する方法が研 究されている ${ }^{(1) \sim(6)}$ 。しかし，現有の方法によれば，最適補 閒円弧のパラメータを決める際に連立非線形方程式を解か なければならない(7)。この実用上の不便さを解消するため に，本研究では，連立非線形方程式を解く必要がない，簡 便なインボリュート曲線の最適円弧補間法を提案する。

\section{2. 補間方法}

$2 ・ 1$ 最適補間円弧のパラメータ Fig. 1 に示すよ うに，円弧でインボリュート曲線を補間する場合，円弧と インボリュート曲線との間に補間誤差の極值点が二つ存在 する。これらの点を $A$ と $B$ とし，かつ円弧がインボリュー ト曲線の右側になるとき補間誤差の值を正, 左側になると きは負とすれば,補間誤差の極値 $a A$ は負, $B b$ は正となる。 補間精度の值が $\pm E$ に指定され, かつ $-a A=B b=E$ が成り立つ 場合は, 次の関係が得られる ${ }^{(6)}$ 。

$$
\left\{\begin{array}{l}
K=R / r_{b} \\
E / r_{b}=\sqrt{K^{2}-1}-\cos ^{-1}(1 / K)=\tan \beta-\beta \\
\rho=r_{b} \theta
\end{array}\right.
$$

上式における $K$ の值が $E / r_{b}$ のみに関係して $\rho$ と $\theta$ とは無関係 である。

一方，円弧がインボリュート曲線に接する場合，その接 点が補間誤差極值点である。もう一つの補間誤差極值点で 補間誤差の絶対值が $E$ であれば，すなわち，Fig. 1 の中に $a A=0$ と $B b=E$, または, $a A=-E$ と $B b=0$ の場合, 文献(6)と 同様な手法を用いれば，次の関係が得られる。

$$
\left\{\begin{array}{l}
K_{1}=R_{1} / r_{b} \\
E / r_{b}=2\left\{\sqrt{K_{1}^{2}-1}-\cos ^{-1}\left(1 / K_{1}\right)\right\}=2\left(\tan \beta_{1}-\beta_{1}\right) \\
\rho=r_{b} \theta \pm 0.5 E
\end{array}\right.
$$

ここで，式(1)に示した状態を区別するために，円弧に関係 するパラメータにサーフィックス 1 をつけた。また，この 場合に補閒誤差の極值点間に対応するインボリュート曲線 の展開角 $\phi$ の幅は $2 \beta_{1}$ である。

2 - 2 最適円胍補間における基本的関倸 平面曲線 の最適円弧補間とは，曲線の両端で円弧が曲線と接し，円 弧間の接続が滑らかで，各円弧における補間誤差の極值が 等しくかつ指定された精度值 $\pm E$ 以内に抑えられ，必要な円 弧の数が最も少ない，という円弧補間である(7)。したがっ

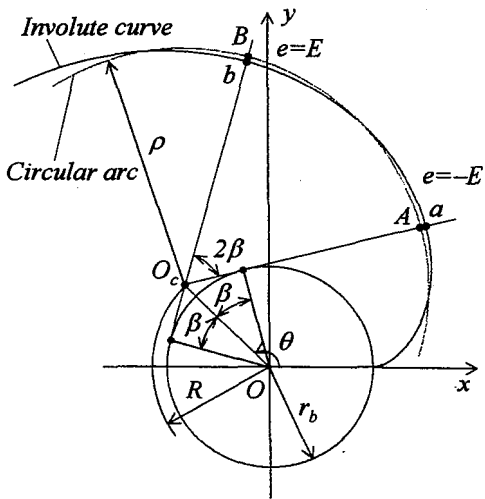

Fig. 1 Interpolation relation of circular arc for involute curve

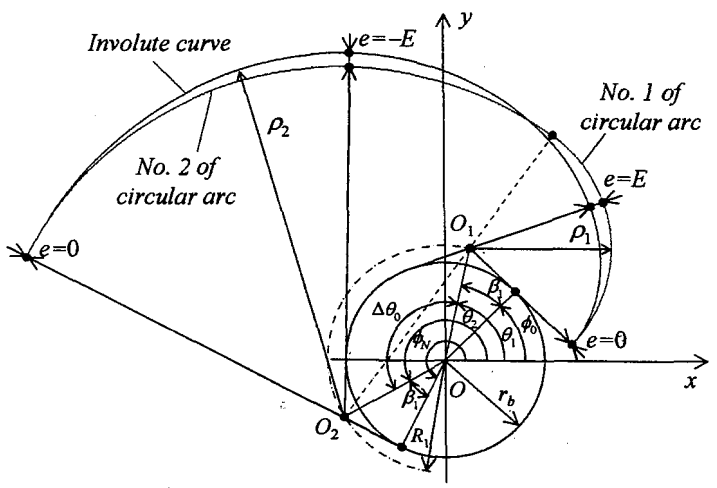

Fig. 2 Optimal interpolation using two circular arcs for an involute curve

て,インボリュート曲線を最適円弧補間する場合には, 曲 線の長さ及び指定された補間精度の值によらず, 少なくと も2 個の円弧が必要となる。

2 個の円弧で補間する場合, 補間誤差の極值士e が指定補 間精度值 $\pm E$ になるときの円弧とインボリュート曲線の関 係を Fig. 2 に示す。この場合, 円弧は式(2)以外に次の式も 満足する。

$$
\left\{\begin{array}{l}
\theta_{1}=\phi_{0}+\beta_{1}, \quad \rho_{1}=r_{b} \theta_{1}+0.5 E, \\
\theta_{2}=\phi_{N}-\beta_{1}, \quad \rho_{2}=r_{b} \theta_{2}-0.5 E, \\
\phi_{N}-\phi_{0}=2 \beta_{1}+\theta_{2}-\theta_{1}=2 \beta_{1}+\Delta \theta_{0}
\end{array}\right.
$$

文献(6)と同様な手法を用いれば，次の関係が得られる。

$$
K_{1} \sin \left(0.5 \Delta \theta_{0}\right)=0.5 \Delta \theta_{0}
$$

一方，2 個以上, 例えば，4 個の円弧で補間する場合, 補間誤差の值 $e$ が指定補間精度值 $E$ になるときの円弧とイ ンボリュート曲線の関係を Fig. 3 に示す。この場合， 1 番 目と 4 番目の円弧は式(2)， 2 番目と 3 番目の円弧が式(1) 


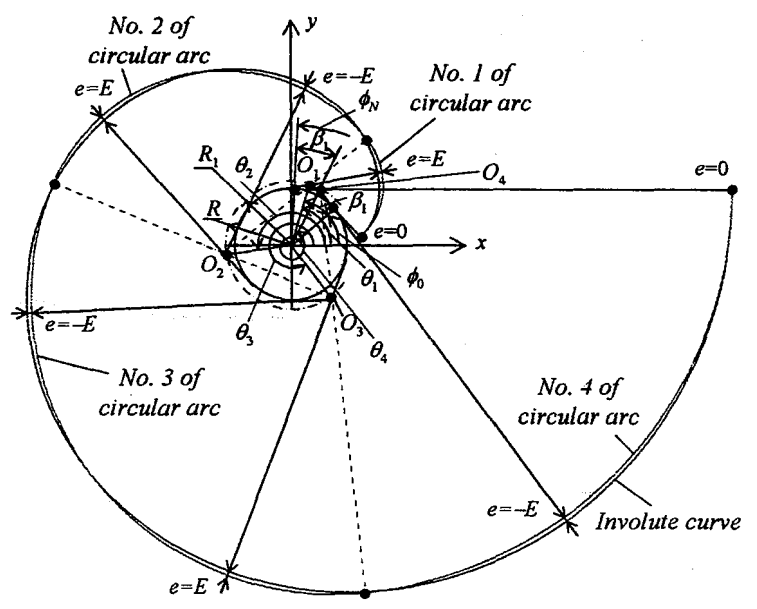

Fig. 3 Optimal interpolation using four circular arcs for an involute curve
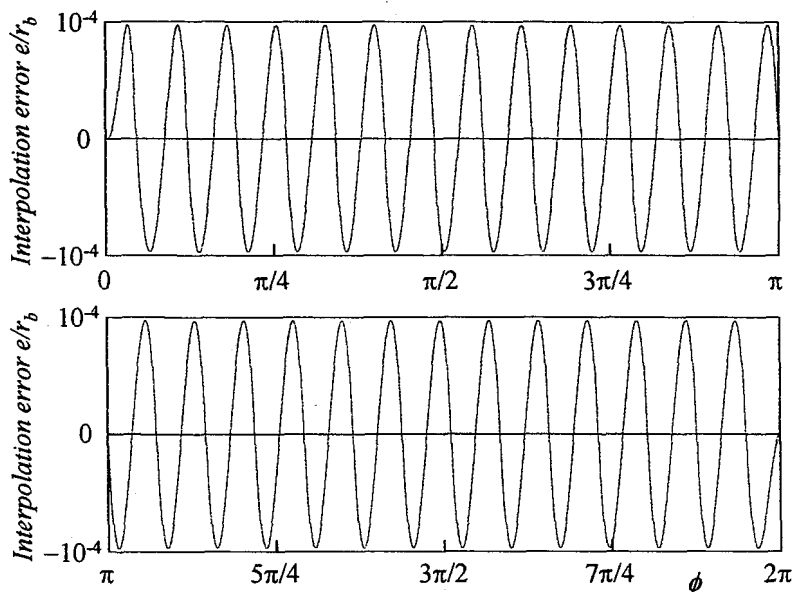

Fig. 4 An example of the obtained interpolation error curve due to a specified accuracy $E / r_{b}=10^{-4}$

をそれぞれ満足し，さらに次の関係が成り立つ。

$$
\left\{\begin{array}{l}
\theta_{1}=\phi_{0}+\beta_{1}, \quad \rho_{1}=r_{b} \theta_{1}+0.5 E, \\
\theta_{2}=\theta_{1}+\left(\theta_{2}-\theta_{1}\right)=\theta_{1}+\Delta \theta_{1}, \quad \rho_{2}=r_{b} \theta_{2}, \\
\theta_{3}=\theta_{2}+\left(\theta_{3}-\theta_{2}\right)=\theta_{2}+\Delta \theta, \quad \rho_{3}=r_{b} \theta_{3}, \\
\theta_{4}=\phi_{N}-\beta_{1}=\theta_{3}+\left(\theta_{4}-\theta_{3}\right)=\theta_{3}+\Delta \theta_{1}, \quad \rho_{4}=r_{b} \theta_{4}-0.5 E, \\
\phi_{N}-\phi_{0}=2 \beta_{1}+2 \Delta \theta_{1}+\Delta \theta_{2}
\end{array}\right.
$$

文献(6)と同様な手法を用いれば，次の関係式が得られる。

$$
K_{1}^{2}-2 K_{1} K \cos \Delta \theta_{1}+K^{2}=\left(\Delta \theta_{1}-0.5 E / r_{b}\right)^{2}
$$

$$
K \sin (0.5 \Delta \theta)=0.5 \Delta \theta
$$

$2 \cdot 3$ 必要な円弧の数 展開角の領域が $\Delta \phi\left(=\phi_{N}-\phi_{0}\right)$ のインボリュート曲線を指定補間精度値 $\pm E$ で最適円弧補 間するときの必要な円弧の数 $n$ は次式による。

$$
\left\{\begin{array}{l}
n=2 \quad \text { if } \Delta \phi \leq 2 \beta_{1}+\Delta \theta_{0} \\
n=3 \quad \text { if } 2 \beta_{1}+\Delta \theta_{0}<\Delta \phi \leq 2\left(\beta_{1}+\Delta \theta_{1}\right) \\
n=3+k \quad \text { if } \Delta \phi>2\left(\beta_{1}+\Delta \theta_{1}\right) \\
k=\left[\Delta \phi-2\left(\beta_{1}+\Delta \theta_{1}\right)\right] / \Delta \theta \quad \text { if }\left[\Delta \phi-2\left(\beta_{1}+\Delta \theta_{1}\right)\right] / \Delta \theta \text { is an integral } \\
\left.k=\operatorname{int}\left\{\Delta \phi \phi-2\left(\beta_{1}+\Delta \theta_{1}\right)\right] / \Delta \theta\right\}+1 \quad \text { for others }
\end{array}\right.
$$

\section{$2 \cdot 4$ 計算アルゴリズム}

(a) $r_{b}, \phi_{0}, \phi_{N}$ と $E$ を入力, $\Delta \phi=\phi_{N}-\phi_{0}$

(b) 式(1) (5)より $K_{1}, \beta_{1} ; K, \Delta \theta_{0}, \Delta \theta_{1}, \Delta \theta$ を求め, 式(6) より必要な補間円弧の数 $n$ を定める。 $n=2$ なら (c)人, $n=3$ なら(d)へ, $n>3$ の場合は(e)へ。

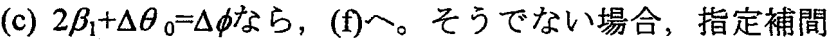
精度值 $E$ の代わりに補閒誤差極值 $e$ を変数として取扱 い, $\beta_{1}$ と $\Delta \theta_{0}$ を $e$ の関数と見直して, 次式を満足する ように $e$ を定め, (f) 一。

$$
\Delta \phi=2 \beta_{1}(e)+\Delta \theta_{0}(e)
$$

(d) $2 \beta_{1}+2 \Delta \theta_{1}=\Delta \phi な ら ，(f)$ へ。うでない場合, $\beta_{1}$ と $\Delta \theta_{1}$ を $e$ の関数として, 次式を満足するように $e$ を定め, (f) $\sim$ 。

$$
\Delta \phi=2 \beta_{1}(e)+2 \Delta \theta_{1}(e)
$$

(e) $2\left(\beta_{1}+\Delta \theta_{1}\right)+k \Delta \theta=\Delta \phi$ なら, (f)へ。そうでない場合, $\beta_{1}$, $\Delta \theta_{1}, \Delta \theta$ を $e$ 関数として, 次式を満足するように $e$ を定め, (f) へ。

$$
\Delta \phi=2\left\{\beta_{1}(e)+\Delta \theta_{0}(e)\right\}+k \Delta \theta(e)
$$

(f) 得られた補間誤差極値 $e$ に基づいて, 各補間円弧の関 係パラメータを決める。

$$
\left\{\begin{array}{l}
\theta_{1}=\phi_{0}+\beta_{1}, \quad \rho_{1}=r_{b} \theta_{1}+0.5 e, \\
\theta_{n}=\phi_{N}-\beta_{1}, \quad \rho_{n}=r_{b} \theta_{n}-0.5 e, \\
\theta_{2}=\theta_{1}+\Delta \theta_{1}, \quad \theta_{n-1}=\theta_{n}-\Delta \theta_{1}, \\
\theta_{i}=\theta_{i-1}+\Delta \theta, \quad(i=3,4, \cdots, n-2), \\
\rho_{i}=r_{b} \theta_{i} \quad(i=2,3, \cdots, n-1)
\end{array}\right.
$$

かつ, $j$ 番目と $j+1$ 番目円弧間の接続点 $\left(x_{j}, y_{j}\right)$ 及びそ れに対忘するインボリュート曲線の展開角 $\phi_{j}(j=1,2, \cdots$, n-1）は次式による。

$$
\left\{\begin{array}{l}
x_{j}=x_{c, j+1}-\rho_{j+1}\left(x_{c, j+1}-x_{c, j}\right) /\left(\rho_{j+1}-\rho_{j}\right) \\
y_{j}=y_{c, j+1}-\rho_{j+1}\left(y_{c, j+1}-y_{c, j}\right) /\left(\rho_{j+1}-\rho_{j}\right) \\
\phi_{j}=\mathrm{a} \tan 2\left(y_{j}, x_{j}\right)+\cos ^{-1}\left(r_{b} / \sqrt{x_{j}^{2}+y_{j}^{2}}\right) \\
x_{c, j}=R \cos \theta_{j}, \quad y_{c, j}=R \sin \theta_{j} \quad(j=2,3, \cdots, n-1), \\
x_{c, j}=R_{1} \cos \theta_{j}, \quad y_{c, j}=R_{1} \sin \theta_{j} \quad(j=1, n)
\end{array}\right.
$$

(g) 計算終了。

\section{3. 補間例}

提案した方法の有効性を確認するために，E/ $r_{b}=10^{-2}, 10^{-3}$, $\cdots, 10^{-8}, \phi_{0}=0, \phi_{N}=2 \pi$ の条件でインボリュート曲線を補間し た。得られた補間誤差曲線の 1 例を Fig. 4 に示す。

\section{4. 結言}

連立非線形方程式を解く必要がなく, 実用上便利なイン ボリュート曲線の最適円弧補間法を提案した。また, 補間 計算の結果から提案手法の有効性が確認された。

\section{文}

(1) D. W. Dudley, Gear Handbook, McGraw-Hill, (1962), 23-19. (2) 会田・寺内 - 平松, 大型歯車用簡易歯形検查機について, 精密機 械, 20-8, (1954), 285. (3) 斉藤 - 石川, 円弧基準式歯形測定機の試 作, 機論, 35-275, C(1969), 1545. (4) 津田 - 石川・福田, 歯車の成 形研削に関する研究, 精密機械, 42-9, (1976), 893. (5) 丘・有浦, インボリュート歯形の円弧近似，機論，55-517, C(1989), 2507. (6) 丘・有浦・尾崎, 指定補間誤差值を持つインボリュート輪郭曲線 の最適円弧補間法, 機論, 60-572, (1994), 1482. (7) 丘・有浦 - 尾 崎, 平面曲線輪郭の精密 N C 加工のための最適円弧補間法, 機論, 62-593, C(1996), 338. 